\title{
Medico-nutritional importance and value added products of pineapple - A Review
}

\author{
*Kapil Kumar, Suresh Chandra, Vishal Kumar and Prince \\ Department of Agricultural Engineering and Food Technology \\ Sardar Vallabhbhai Patel University of Agriculture and Technology, Meerut-250110 (U.P.) \\ *Corresponding Author: kumar89kapil@rediffmail.com
}

\begin{abstract}
Pineapple a tropical fruit contains a proteolytic enzyme bromelain, which helps in the digestion of protein prevent blood clot formation. Pineapple's nutrients include calcium, potassium, fiber, and vitamin C. It is low in fat and cholesterol. It is also a good source of vitamin B1, vitamin B6, copper and dietary fiber. Pineapple is a rich source of ascorbic acid supplement to our diet. Pineapple pulp waste showed maximum amount of reducing sugars $(30.5 \mathrm{mg} / 100 \mathrm{~g})$ and ash $(1.8 \mathrm{mg} / 100 \mathrm{~g})$ respectively. Pineapple waste contains high concentration of biodegradable organic material and suspended particles. Pineapple waste showed higher concentration of crude fibre, non-reducing sugar, protein, ascorbic acid and moisture content. Therefore pineapple waste is used as substrate for growth of microbes in fermentation process. Pineapple leaf fibre is very common in tropical regions and very simple to extract fibres from its leaves. The utilization of pineapple leaf fibre in composite material is a new source of materials which can be economic, eco-friendly, and recyclable. However, the main issue of pineapple leaf fibre is its hydroscopic nature, which makes a big hurdle for fibre utilization as a reinforced material in polymer composites. Surface modification of PALF is required to improve for good interfacial adhesion of PALF with polymers in fabrication of polymer composites.
\end{abstract}

Keywords : Pineapple, Bromelain, PALF, antioxidant, value added product.

Paper Cited: Kumar, K., Chandra, S., Kumar, V. and Prince (2016). Medico-nutritional importance and value added products of pineapple - A Review. South Asian Journal of Food Technology and Environment, 2(1): 290-298.

Received: 18/01/2016 Revised: 30.01.2016 Accepted: 07/02/2016

\section{Introduction}

Pineapple (Ananas cosmosus) is a tropical fruit which grows in countries which are situated in the tropical and sub-tropical regions. It is native to Central and South America. Nowadays, it is cultivated in low altitudes in several countries where the weather conditions are favorable. Pineapple belongs to the Bromeliaceous family and grows on the ground. It can grow up to $1 \mathrm{~m}$ in height and $1.5 \mathrm{~m}$ wide. The pineapple is considered the third most important tropical fruit produced in the world, after the banana and citric fruits. In international trade, the numerous pineapple cultivars are grouped into four main classes, Smooth Cayenne, Red Spanish, Queen and Abacaxi, although there is much variation within each class (Bartolome and Ruperez, 1995). There are many cultivars of Ananas, but the predominant one is 'Smooth Cayenne'(Samson 1986). Total pineapple production worldwide is around 16 to 18 million tons. Fernandes et al., 2008). There are several countries (i.e. Thailand, Brazil, India, Phillipines and China) which contribute to the total production. Pineapple is an important food which can be eaten fresh or eaten in a processed form. It is composed of nutrients which are good for human health. This is due to researches carried out on the relationship between nutrients in pineapple and human health. Processing pineapple in industries can leave a lot of waste which can cause serious environmental problems. Researchers have been carried out recently to counteract this problem.

Pineapple mainly contains water, carbohydrates, sugars, vitamins $\mathrm{A}, \mathrm{C}$ and betacarotene. It contains low amounts of protein, fat, 
ash and fibre. Pineapples contain antioxidants namely flavonoids, vitamin $\mathrm{A}$ and $\mathrm{C}$. These antioxidants reduce the oxidative damage such as that caused by free radicals and chelating metals. It also has the enzyme complex protease (bromelain). Bromelain contains peroxidase, acid phosphate, several protease inhibitors and organically bound calcium (Tochi et al., 2008). Most of the commercial pineapple produced worldwide is canned prior to consumption; however, the fresh fruit market is increasing. Despite its favorable acceptance by consumers in North America and Europe, fresh pineapple has a few commercial limitations due to some deficiencies in the most widely cultivated variety in the world (Smooth Cayenne): high acidity, low concentration of ascorbic acid, little flavor and a texture defect known as translucency (Paull and Chen, 2003). Because it is a non-climacteric fruit and seemingly has no carbon source for promoting post-harvest sweetening, the pineapple must be harvested sweet; sugar levels in pineapples will not accumulate post-harvest. Only the natural decrease in the organic acids present in the fruit might improve the post-harvest flavor of either a naturally low-sugar fruit or the one harvested early.

The average pineapple weighs between 1 and $2 \mathrm{~kg}$, and with regard to its consumption and utilization, it consists of the pulp, shell and core. The pulp, which is approximately $80 \%$ water, is consumed not only in nature but also in multiple processed forms, including juice, jam, dehydrated, canned or even frozen. Sub products of pineapple processing include alcoholic beverages, organic acids, and the enzyme bromelain, which is a protease that is involved in the composition of several medicines and is also used as a meat softener. Both the shell and core of the pineapple are used for producing juices, because of their potential sources of fiber. Pineapple fiber is considered softer in texture than many vegetable sources, and some of its natural characteristics make it favorable for use in the food industry. These characteristics include its white color, its high retention of colorants and its high resistance to salts, vapor and traction (Rohrbach et al., 2003). Currently there is no literature available on the pineapple core, probably because it is usually disposed of when canned pineapple is produced. The consumption of rapidly digestible carbohydrates leads to fast increases in blood glucose and insulin. Therefore, meals rich in carbohydrates result in a rapid elevation of blood glucose levels (Menezes et al., 2006). The biomarkers known as the glycemic index (GI) and glycemic load (GL) classify the quality of carbohydrates and foods, respectively, according to their capacity to increase blood glucose. Knowing that foods have a low GI or low GL may facilitate dietary planning and, thus, regulating glycemic levels.

\section{Chemical composition of pineapple}

The pineapple fruit was divided into three main parts for the investigation of its utilization as in natura or processed pulp, or as the shell (as a fiber source) and the core, which is removed when the pulp is canned. Moisture in the pulp was around $15 \%$ higher than in the shell and core. The level of protein was higher in the core $(35 \%)$ than in the pulp or the shell. Among the edible in natura components, the concentration of ash in the pulp was $25 \%$ higher than in the core. The varying concentrations of iron and calcium in the shell of the fruit are noteworthy. Each $100 \mathrm{~g}$ of shell has amounts of calcium and iron that correspond to 40 and $70 \%$ of the recommended daily intake for these minerals, respectively. In the case of the pulp, these values are 5 and $22 \%$, respectively, which are not relevant from a nutritional point-of-view (FAO, 2002). Chemical composition of pineapple is given in Table 1.

In order to explore suitability of any fruit for fresh market and processing industry, it is important to study the physico-chemical characteristics of the fruit of such fruit cultivar. The chemical composition of pineapple fruit depends upon number of important factors, including variety, nutrition, exposure to light, weather (light intensities, day and night temperature, rainfall or irrigation, season), free from blemishes, insects and diseases (Kerns et al., 1936). The vitamin $C$ was not distributed uniformly within the fruit of pineapple, but showed a great concentration near the inner surface of the shell with a small amount located in the regions near the corn. Ascorbic acid or vitamin C plays an important role in human 
nutrition. Lal and Pruthi (1955) reported that the ascorbic acid content of Kew or Giant Kew and Mauritius varieties of pineapple varied from 6.1 to $2.6 \mathrm{mg} / 100 \mathrm{~g}$ of edible portion. Mookerji et al., (1969) found that total soluble solid content in the fruits of cultivar Kew increases gradually and was maximum $(16.5 \%)$ at ripening, while, Bhat et al., (1977) observed that the fruits of cultivar Giant Kew contained 14 per cent total soluble solids. In contrast, Ahmed and Bora (1989) revealed that there was no significant difference in total soluble solid content in the fruits of cultivar Kew harvested during different months of the year. Nakatoh et al., (1985) found that summer fruits of pineapple had higher total soluble solids than winter fruits and also observed that the flesh and the peduncle portion were richest in total soluble solids.

The moisture content in the fruits of cultivar Kew at ripening was found to be 78.52 percent (Mookerji et al., 1969), while Bhat et al., (1977) reported the fruits of Giant Kew contained 81.6 per cent. Jayaraman et al., (1975) and Sen (1990) observed 84.9 and 85.0 per cent moisture content, respectively, in pineapple. Mookerji et al., (1969) found that ripened fruits of cultivar Kew contended 5.1 percent reducing sugar, 9.0 percent non-reducing and 14.0 percent total sugar. Similar observations were also recorded by Maurya (1988), and Bhat et al., (1977) found that the cultivar giant Kew contained 3.12 percent reducing sugar, 9.36 percent non-reducing sugar and 12.48 percent total sugar. Jayaraman et al., (1975) found that the pineapple fruits contained 4.8 percent reducing sugar and 11.4 per cent total sugar. Jayaraman et al., (1975) reported that acidity of edible portion of pineapple was 0.87 per cent. Similar level of acidity $(0.83 \%)$ was also reported in Giant Kew by Bhat et al., (1977). Sen (1990) reported that 0.6 gram acid was present in 100 gram edible portion of pineapple fruit. However, Kumar et al., (1991) noticed variation of 0.9 to 1.1 per cent acidity in the fruits of Giant Kew.

Bhat et al., (1977) observed that the ascorbic acid content varied from 20.2 to 31.2 $\mathrm{mg} / 100 \mathrm{~g}$ in 16 varieties of pineapple, among them the Giant Kew contained $31.2 \mathrm{mg}$.
However, Sen (1990) observed that $100 \mathrm{~g}$ of edible portion of pineapple fruit contained $63 \mathrm{mg}$ Vitamin C. Analysed 16 varieties of pineapple fruits and found that the ash content was varied 0.31 to 0.47 percent, the Giant Kew recorded the lowest content of ash $(0.31 \%)$. One hundred gram edible portion of pineapple fruit was found to contain $0.05 \mathrm{~g}$ mineral matters (Sen, 1990). Nakatoh et al., (1985) found that summer fruits of pineapple had lower ash content than winter fruits.

Sen (1990) reported that pineapple fruit contained 60 I.U. vitamins A. According to Kumar et al., (1991), the total carotene analysis showed high carotene content in the juice which ranged from 300 to 400,70 to 250 and 50 to 150 microgram in Queen, Giant Kew and Mauritius varieties of pineapple. Carotene, which is a precursor of vitamin A, is found in most of the fruits in varying quantity. Pineapple is a good source of carotene. The pineapple fruits contained 13.0 percent sugar. Sugars are related with sweetness, flavour, colour and structure of fruits.

The total soluble sugars found in the pineapple fruit (between 7 and 12\% in the fresh weight of the core and pulp) were predominantly sucrose, fructose and glucose. The core has almost twice as much (12\%) sugar (glucose, fructose and sucrose) than the pulp (6.8\%). Furthermore, the concentration of sucrose is higher in the core than in the pulp, as the ratios of suc:glc+fru are 6.2 and 4, respectively. These results from the pulp are similar to the ones found in Smooth Cayenne and Red Spanish cultivars (Bartolome et al., 1995). The concentration of fructans $(\sim 0.1 \%)$ was the same as that found for starch. It is known that the concentration of starch, which is relatively high during the fruit development ( $4 \%$ ) (Paull and Chen, 2003), is low in developed fruit, but this had not previously been quantified in ripe fruit. In relation to the fructans, this is the first time that this fructose polymer was identified and quantified in pineapple. Because this fructose polymer has never been detected in Bromeliaceae, this data needs to be confirmed by a second methodology. The insoluble dietary fiber was found to be around $1 \%$ and the soluble 
dietary fiber was less than $0.1 \%$, with the total fiber concentration being comparable to the Smooth Cayenne cultivar (Gorinstein et al., 1999). Guevarra and Panlasigui (2000) found less than $1 \%$ of dietary fiber and negligible amounts of soluble fiber in this fruit.

\section{Vitamin $C$ and Organic Acids}

The pineapple presented relatively low concentrations of total ascorbic acid in the edible parts, levels of ascorbic acid were higher in the shell, as expected, due to its protective antioxidant function (Smirnoff, 1996). This fact is corroborated by the high concentration of dehydroascorbic acid (DHAA) in the shell (1/3 of the total), whereas the concentration of DHAA was approximately $10 \%$ of the total in the pulp and core, as in some vegetables (Smirnoff, 1996). The core presented the lowest concentration of vitamin C ( 12 mg.100 g$\left.{ }^{1} \mathrm{FW}\right)$.

Free acids increase from the bottom of the fruit to the top, and to an even greater extent from the center towards the outside: $0.6 \mathrm{~g} .100 \mathrm{~g}$ ${ }^{1}$ core, 1.1 g. $100 \mathrm{~g}^{-1}$ pulp and $2.8 \mathrm{~g} .100 \mathrm{~g}^{-1}$ shell. The typical content of organic acids of fruit pulp ranges from 0.5 to $1.6 \quad$ g. $100 \mathrm{~g}^{-1} \mathrm{FW}$; approximately $60 \%$ is citric acid, $36 \%$ is malic acid, and traces of succinic, oxalic and nonidentified acids are also found (Py et al., 1987). Furthermore, these values vary during pineapple growth and development, with the citric acid content changing from $0.1 \mathrm{~g} .100 \mathrm{~g}^{-1}$ to $0.7 \mathrm{~g} .100$ $\mathrm{g}^{-1}, 6$ and 15 weeks after flowering, respectively, in Smooth Cayenne (high acid and low acid clones) (Saradhuldhat and Paull, 2007). The results obtained for the Perola variety pulp (1.1 g.100 $\mathrm{g}^{-1} \mathrm{FW}$ ) were also within this range, as was the citric acid content (61\%). However, the percentage of malic acid was higher than that reported by Py et al., (1987). There is no information available about the organic acid content of the other parts of pineapple.

\section{Non-Starch Polymers of Pineapple}

The high content of galactose, associated with the presence of rhamnose, suggests a high amount of pectic polysaccharides. This pectin probably has a high quantity of branching points with neutral arabinogalactans (still unknown whether type I or II) and possibly arabinoxilan, a polymer that is composed of a main chain of xylose branched with arabinose. These components act mainly as soluble dietary fiber in the diet. The presence of relatively high proportions of xylose among the soluble polysaccharides suggests the presence of arabinoxylans. However, the presence of this polymer will have to be confirmed by structural analysis. If, indeed, this is confirmed, an important point to be stressed is that arabinoxylans have been shown to be implicated as a fiber hemicellulose associated with the decrease of glycemic levels in animals (De Paula et al., 2005). Table 2 shows the water soluble polymeric carbohydrates in the pulp of pineapple.

Table 1: Chemical Composition of Pineapple

\begin{tabular}{|l|c|l|}
\hline Nutrients & Units & Value per 100 g \\
\hline Water & $\mathrm{g}$ & 86.00 \\
\hline protein & $\mathrm{g}$ & 0.54 \\
\hline total lipids & $\mathrm{g}$ & 0.12 \\
\hline Ash & $\mathrm{g}$ & 0.22 \\
\hline Carbohydrates & $\mathrm{g}$ & 13.22 \\
\hline Fibre & $\mathrm{g}$ & 1.4 \\
\hline Sugar & $\mathrm{g}$ & \\
\hline Sucrose & $\mathrm{g}$ & \\
\hline glucose & $\mathrm{g}$ & 9.85 \\
\hline Fructose & $\mathrm{g}$ & 9.85 \\
\hline \multicolumn{3}{|c|}{ Vitamins } \\
\hline Vitamin C & $\mathrm{mg}$ & 47.8 \\
\hline Vitamin A & $\mathrm{IU}$ & 58.0 \\
\hline \multicolumn{3}{|c|}{ Others } \\
\hline Carotene & mg & 35 \\
\hline
\end{tabular}

Source: USDA Nutrient Database

The dietary fiber content and composition of pineapple flesh has been reported by different authors (Lund and Smoot, 1982; Bartolome and Rupérez, 1995) and Bartolome et al., (1995) reported on the partial characterization of the hemicellulosic fraction from pineapple fruit cell walls. However, there is little published information about the indigestible fraction in pineapple pulp. The dietary indigestible fraction (DIF) is defined as the part of vegetable foods that is neither digested nor absorbed in the small intestine, and therefore reaches the colon, where it serves as a 
substrate for fermentative microflora. It comprises dietary fiber, resistant protein, resistant starch and other indigestible associated compounds, such as cell wall polysaccharides. The analytical methodology for DIF determination in foods has already been reported (Saura-Calixto et al., 2000).

\begin{tabular}{|c|c|c|}
\hline $\begin{array}{l}\text { Table 2: } \\
\text { carbohydrate } \\
\left(\text { g.100g }{ }^{-1} \text { dry }\right.\end{array}$ & & $\begin{array}{l}\text { ter-soluble } \\
\text { the pulp of polymeric } \\
\text { theapple }\end{array}$ \\
\hline $\begin{array}{l}\text { Mono- } \\
\text { saccharide } \\
\text { s }\end{array}$ & $\%$ & $\begin{array}{l}\text { Possible } \\
\text { polysaccharides }\end{array}$ \\
\hline Galactose & $\begin{array}{l}36 . \\
7\end{array}$ & $\begin{array}{l}\text { Galactan/arabinogalacta } \\
\mathrm{n}\end{array}$ \\
\hline Arabinose & $\begin{array}{l}24 . \\
3\end{array}$ & $\begin{array}{l}\text { Arabinan/ } \\
\text { arabinogalactan }\end{array}$ \\
\hline Xilose & $\begin{array}{l}21 . \\
6\end{array}$ & $\begin{array}{l}\text { Xyloglucan/arabinoxyla } \\
\text { n }\end{array}$ \\
\hline Glucose & 6.9 & Starch/xylogluocan \\
\hline Mannose & 6.3 & Mannan/galactomannan \\
\hline Fucose & 3.1 & Xyloglucan \\
\hline Rhamnose & 1.0 & Rhamnogalacturonan \\
\hline
\end{tabular}

Source: Cordenunsi et al., (2010)

The total indigestible fraction from pineapple pulp (14.96\% DW) had a high amount of insoluble fraction, with the insoluble fraction being its main constituent $(89 \%$ of total indigestible fraction) and the soluble fraction accounting for only $10 \%$ of total indigestible fraction. The high amount of the insoluble indigestible fraction suggests that the hemicellulose, klason lignin and cellulose fractions (Huber et al., 1983) are the main components of the indigestible fraction. In fact, the cellulose and hemicelluloses fractions were reported as the major constituents in the fiber composition of fresh pineapple (Lund and Smoot, 1982; Bartolome et al., 1995). A fraction of resistant protein can be expected in the insoluble IF, as occurs in other fruits (JiménezEscrig et al., 2001; Bravo et al., 1999).

\section{Antioxidant Activity and Dietary Fiber in Pineapple}

Polyphenols and antioxidant activity (AA), which are a property derived from these bioactive compounds, associated with dietary fiber (Larrauri et al., 1997), were evaluated in the shell, pulp and core of the pineapple fruit. The AA values and polyphenol concentrations of pineapple are shown in, the concentration of polyphenols (ca. $0.5 \%$ for pulp and $0.23 \%$ for core) is within the same range as in the nectarine (0.54\% DW) (Cieslik et al., 2006), but quite lower than the concentration found in guava fruit (2.62\% DW) (Jimenez-Escrig et al., 2001). Also there is less AA antioxidant activity than in persimmons $\left(406 \mu \mathrm{mol} . \mathrm{g}^{-1} \mathrm{DW}\right)$ or guava fruit $\left(238 \mu \mathrm{mol} . \mathrm{g}^{-1} \mathrm{DW}\right)$. These differences are due to the presence of different polyphenols in each fruit; myricetin was the major polyphenol identified in pineapple fibers (Larrauri et al., 1997), whereas catechin is the principal phenolic compound in persimmons. Perola showed the highest polyphenol concentration $(0.49 \%)$ and antioxidant activity $\left(33 \mu \mathrm{mol} . \mathrm{g}^{-1}\right)$ in the pulp and shell. The level of AA is correlated with the amount of polyphenols; the higher polyphenol concentration, the higher the AA. Differences between the pulp, shell, and core polyphenols are due to many different factors, but all of them relate to the pineapple variety, stage of pineapple maturity and storage post harvesting.

\section{Health benefits}

Potential Anti-Inflammatory activity: Bromelain have actions involving other enzyme system in exerting its anti-inflammatory effect on soft tissue injury. It can also inhibit the inflammatory pain in rats in a dose dependent manner (Inoue et al., 1994). Pre-clinical and clinical trials of systemic enzyme therapy in rheumatic disorders showed that proteolytic enzymes certainly have analgesic and antiinflammatory effect (Leipner et al., 2001). As a result of its anti-inflammatory effect, bromelain has been found to dramatically reduce post operative swelling and pain (Seltzer et al., 1962). Plasmakinins and prostaglandins have an important role in playing as mediators of pain and inflammation. (Oh-Ishi et al., 1979) reported that bromelain can lower the plasmakinin level. It was also demonstrated that oral administration of bromelain can reduce the level of both $\mathrm{PGE}_{2}$ and thrombaxane $\mathrm{B}_{2}$ (Vellini et al., 1986).

Antioxidant Protection and Immune Support: Vitamin $\mathrm{C}$ is the body's primary water-soluble 
antioxidant, defending all aqueous areas of the body against free radicals that attack and damage normal cells. Free radicals have been shown to promote the artery plaque build-up of atherosclerosis and diabetic heart disease, cause the airway spasm that leads to asthma attacks, damage the cells of the colon so they become colon cancer cells, and contribute to the joint pain and disability seen in osteoarthritis and rheumatoid arthritis. This would explain why diets rich in vitamin $\mathrm{C}$ have been shown to be useful for preventing or reducing the severity of all of these conditions. In addition, vitamin $\mathrm{C}$ is vital for the proper function of the immune system, making it a nutrient to turn to for the prevention of recurrent ear infections, colds, and flu.

Manganese and Thiamin (Vitamin $B_{1}$ ) for Energy: Pineapple is an excellent source the trace mineral manganese, which is an essential cofactor in a number of enzymes important in energy production and antioxidant defenses. For example, the key oxidative enzyme superoxide dismutase, which disarms free radicals produced within the mitochondria (the energy production factories within our cells), requires manganese. In addition to manganese, pineapple is a good source of thiamin, B vitamin that acts as a cofactor in enzymatic reactions central to energy production.

Protection against dermatological disorders: Bromelain among other fruit extracts from apricots, apples, peaches, pears, papayas, pomegranates, cherries, kiwis, tangerines and oranges have been described to play an important role in treating dermatological disorders (Murad 2003). Ozlen (1995) has disclosed a cosmetic composition containing at least one alpha-hydroxy acid, salicylic acid and at least one digestive enzyme derived from fruit. Preferably the digestive enzyme is a mixture of bromelain and papain. Bromelain is disclosed as being typically obtained from pineapple and papain is disclosed as being typically obtained from dry papaya latex. The compositions are allegedly useful for treating various cosmetic conditions or dermatological disorders, such as lack of adequate skin firmness, wrinkles and dry skin.

\section{Processing}

In India, bulk of ripe pineapple fruits is consumed locally in the fresh form. Fruits are, generally, available throughout the year. A very little attention has been given to utilize this fruit in processing industry. Hence, pineapple fruits have great potentiality in the processing industry. The cultivar Kew has been found most suitable for canning, very little work has been done pertaining to its suitability for beverages, jam and candy of the fruit core.

\section{Value added products}

Dried pineapple: In this product, most of the free water of the fruit is eliminated. Usually, chunks or slices are prepared for better presentation and make handling easier. Final moisture is near $5 \%$, and this allows the dried fruit to have a long shelf life as long as proper packing is provided and storage is done in a fresh place.

Juice: Pineapple juice is obtained from crushing fruit pieces and proper physical separation of the solids. Juice must be pasteurized and packed to extend its shelf life and a preservative or refrigerated storage may be used as additional barriers to microbial spoilage. No juice should reach the market if it becomes fermented or mixed with water. Packing may be plastic bottles or bags, coated cans, multilaminate (plastic, paper, metal foil) or any newer materials. The $\mathrm{pH}$ values of the product must be controlled so it remains agreeable for human consumption. It is a common practice to blend batches of juices to attain proper acidity and sensory qualities. Juices from other fruits can be blended with pineapple's and interesting mixtures make novel products.

Nectar: It is the product of blending juice with a certain amount of solids from the pulp containing the same amount of ${ }^{\circ} \mathrm{Bx}$ as the original fruit. Normally, nectars are prepared by diluting fruit pulp to $30{ }^{\circ} \mathrm{Bx}$. Methods of preservation and packing are similar to those described for juice.

Jelly: Jellies fall in the group of fruit preserves, which are defined as semisolid products prepared by mixing 45 parts of fruit and 55 parts of sugar. This mixture is cooked until the final solids contents reach 65 to $68 \%$. It is hot-filled 
for better stability. Usually, jellies are prepared from fruit juice and a gel-type product is obtained; it may or may not contain fruit pieces. Final textural firmness is dependent of the type of gel-forming agent as pectin which is added under controlled acidity and solids content to assure the proper texture of the product. To assure proper shelf life at ambient temperature, preservatives may be added. These chemicals are mainly used to control mold growth; but once the jar is open, it shall be stored under refrigeration.

Vinegar: Vinegar is prepared by an acetic fermentation of alcohol solutions derived from sugar or starchy materials (fermentable sugar content of $8-20 \%$ ). This is done by strains isolated from the raw materials. Peel and other pineapple by-products from processing can be used as raw materials to prepare natural vinegar and thus make a proper use of residuals. Vinegar must be pasteurized once it is prepared and bottled. It is stable at ambient temperature (Coveca, 2002).

\section{Conclusion}

The edible parts of the pineapple fruit (pulp and core) are rich in soluble carbohydrates and relatively poor in antioxidants and minerals. However, as these fruit tissues are also relatively poor in dietary fiber, the unstirred water layer effect is not expected to occur when pineapple is ingested alone. Therefore, the absorption of minerals and antioxidants would probably be higher due to the lack of interference by the dietary fiber. This fruit in natura is classified as having a low dietary glycemic load $(\mathrm{GL}=7)$, because the usual portion ( $100 \mathrm{~g})$ contains a low concentration of available carbohydrates $(11 \mathrm{~g})$ and a high moisture content $(90 \%$ approximately). The nutritional composition of the shell and core shows that they cannot be disregarded as a source of a high quality fiber for use in food industry.

\section{References}

1. Ahmed, F. and Bora, P.C. (1989). Changes in quality fruit at different times. Journal of Food Science and Technology, 26: 51-53.
2. Bartolome, A.P. and Ruperez, P. (1995). Dietary fiber in pineapple fruit. Journal of Clinical Nutrition, 49( S2): 61-S263.

3. Bartolomé, A. P., Rupérez, P. and Fúster, C. (1995). Pineapple Fruit: Morphological Characteristics, Chemical Composition and Sensory Analysis of Red Spanish and Smooth Cayenne Cultivars. Food Chemistry, 53: 75 - 79.

4. Bhat, A.V., Varkey, A.G., Krishnan Kutty, S. and Pruthi, J.S. (1977).Varietal trials in canning of pineapples. Indian Food Packer, 31 (2): 18-25.

5. Bravo, L., Siddhuraju, P. and SauraCalixto, F. (1999). Composition of underexploited Indian pulses. Comparison with common legumes. Food chemistry, 64 (2): 185-192.

6. Cieslik E., Gręda A. and Adamus W. (2006). Contents of polyphenols in fruit and vegetables. Food Chemistry, 94: 135-142.

7. Cordenunsi, B., Saura-Calixto, F., DiazRubio, M.E., Zuleta, A., Tiné, M.A., Buckeridge, M.S., da Silva, G.B., Carpio, C., Giuntini, E.B., de Menezes, E.W., Lajolo, F. (2010). Carbohydrate composition of ripe pineapple (cv. Perola) and the glycemic response in humans. Ciência e Tecnologia de Alimentos, 30(1): 282-288.

8. Coveca. (2002). Comisionveracruzana de comercializacion a gropecuaria. Gobiernodel Estadode Veracruz, México.

9. De Paula, R., Ding, X., Dourish, P., Nies, K., Pillet, B., Redmiles, D., Ren, J., Rode, J. A. and Silva Filho, R. (2005). Two Experiences Designing for Effective Security. Institute for Software Research, Irvine, $C A$. Working Paper.

10. FAO. (2002), Statistical database. Tropical foods commodity notes.

11. FAO. (2004), Statistical database.

12. Fernandes, J.M., Macqueen, D.J., Lee, H.T., and Johnston, I.A. (2008) Genomic, evolutionary, and expression analyses of cee, an ancient gene involved in normal growth and development. Genomics, 91(4): 315-325.

13. Gorinstein, H., Zemser, M., Haruenkit, R., Chuthakorn, R., Grauer, F., Martin- 
Belloso, O. and Trakhtenberg, S. (1999). Comparative content of total polyphenols and dietary fiber intropical fruits and persimmon. Journal of Nutritional Biochemistry, 10: 367-371.

14. Guevarra, M.T.B. and Panlasigui, L.N. (2000). Blood glucose responses of diabetes mellitus type II patients to some local fruits. Asian Pacific Journal Clinical Nutrition, 9:303- 308.

15. Huber, W., Poeck, K., and Weniger, D., (1983). "Aachener Aphasie Test (AAT)."Hogrefe, Göttingen.

16. Inoue, K., Motonaga, A., Dainaka, J., Nishimura, T., Hashii, H., Yamate, K., Ueda, F. and Klmura, K., (1994). Effect of etodolac on prostaglandis E2 biosynthesis, active oxygen generation and bradykinin formation, Prostaglandins Leukot Essent Fatty Acids, 51: 457-462.

17. Jayaraman, K.S., M.N. Ramanuja, M.K. Venugopalan, R.K. Leela and B.S. Bhatia (1975). Studies on the preparation of Intermediate Moisture pineapple. Journal Food Science Technology, 12 (6): 309312.

18. Jimenez-Escrig, A., Rincon, M., Pulido, R. and Calixto, F. (2001). Guava fruit (Pridiumguajava L.) as a new source of antioxidant dietary fiber. Journal of Agricultural Food Chemistry, 49 (11): 5489-5493.

19. Kerns, K.R., Collins, J.L., Kim, H. (1936). Developmental studies of the pineapple Ananas comosus (L.) Merr.The New Phytologist, 35: 305-317.

20. Kumar, H.S.P., Jayathilakan, S. and Vasundhara (1991). Factors affecting the quality of freeze dried pineapple juice powder. Indian Food Packer, 45 (2): 511.

21. Lal, G. and J.S. Pruthi (1955). Studies the technological aspects of the manufacture of passion fruit juice and squash. Indian Journal Horticulture, 12 (3): 137.

22. Larrauri, J. A., Ruperez, P. and Calixto, F.S. (1997). Pineapple shell as a source of dietary fiber with associated polyphenols. Journal of Agricultural and Food Chemistry, 45: 4028-4031.
23. Lee, S.C. and Prosky, L. and Devris, J.W. (1992). Determination of total, soluble, and insoluble dietary fiber in foods: Collaborative study. Journal Association Official Analytical Chemists, 75: 395416.

24. Leipner, J., Iten, F. and Saller, R, (2001). Therapy with proteolytic enzymes in rheumatic disorders. Biological Drugs, 15(12): 779-789.

25. Lund, E.D. and Smoot, J.M. (1982). Dietary fiber content of some tropical fruits and vegetables. Journal of Agricultural and Food Chemistry, 30: 1123-1127.

26. Maurya, R.K. (1988). Predicting maturity of pineapple var. Kew. Indian Food Packer, 42 (1): 43-45.

27. Menezes, E.W., Lajolo, F.M., Marcadores. (2006), in vivo e in vitro de carboidratos. In: LAJOLO, F.M.; MENEZES, E.W. ed. Carbohidratos en alimentos regionales iberoamericanos. Proyecto CYTED/CNPq XI.18. Composición, Estructura, Propiedades Biológicas de Carbohidratos y su Utilización en Alimentos. São Paulo: EDUSP. p. 309-334.

28. Mookerji, K.K., Bhat, A.V., Satyavati V.K. and Chitradevi, A.K. (1969). Optimum harvest maturity for the economic and quality canning of pineapple slices and juices. Indian Food Packer, 23 (6): 29-33.

29. Murad, H. (2003). Method of treating dermatological disorders with fruit extracts. In: patent, U.S. (Edition). P. 138.

30. Nakatoh, H., Ohta, H. and Nasiro, S. (1985). Quality of pineapple fruit and processed juice from different growing seasons in Okinawa. Journal of Japanese Society of Food Science and Technology, 32(12): 911 - 915.

31. Oh-Ishi, S., Yasuhiro, U., Ueno A. and Katori, M. (1979). Bromelain: 
Athiolprotease from pineapple stem, depletes high molecular weight kininogen by activation of Hageman factor (factor X11), Thrombosis Research, 14 (4-5): 665-672.

32. Ozlen, S. N., (1995). Cosmetics composition containing alpha hydroxyacids, salicyclic acid and enzyme mixture of bromelain and papain.In: Patent, U.S. (Ed.) United states: Longevity network Ltd. Handerson, Nev 1995, 1-6.

33. Paull, R.E. and Chen, C.C. (2003). Postharvest physiology, handling and storage of pineapple. pp 253-279. In: Pineapple: Botany, Production and Uses. Bartholomew, D.P., Paull, R.E., Rohrbach, K.G., (eds.) CABI, Wallingford, UK.

34. Py, C., Lacoeville, J.J., Teisson, C. (1987). The Pineapple, Cultivation and Uses. Maisonneuveet Larose G.P (eds). Paris, France.

35. Rohrbach, K.G., Leal, F., and d'Eeckenbrugge, C.G. (2003). History, distribution and world production. In: D.P. Bartholomew, R.E. Paull, and K.G. Rohrbach, (Eds.), The Pineapple: Botany, Production and Uses. CAB International, Wallingford, UK, pp. 1-12.

36. Samson, J. A. (1986). Tropical Fruits. 2 ed. New York: Longman Inc.

37. Saradhuldhat, P. and Paull. R. E. (2007). Pineapple organic acid metabolism and accumulation during fruit development. Scientia Horticulturae, 112: 297-303.

38. Saura-Calixto, F., García-Alonso, A., Goñi, I. and Bravo, L. (2000). In vitro determination of the indigestible fraction in foods: an alternative to dietary fibre analysis. Journal of Agriculture Food Chemistry. 48: 3342-3347.

39. Seltzer, A.P. (1962). Minimizing post operative edema and ecchymoses by the use of an oral enzyme preparation (bromelain). EENT Monthly, 41: 813817.

40. Sen, S.K. (1990). Pineapple. In: Fruit: Tropical and Subtropical. Edited by T.K.
Bose and S.K. Mitra, Naya Prokash, Calcutta-6, India.

41. Smirnoff, N. (1996). The function and metabolism of ascorbic acid in plants. Annals of Botany, 78: 661-669.

42. Tochi, B.N., Wang, Z., Xu, S.Y. and Zhang, W. (2008). Therapeutic Application of Pineapple Protease (Bromelain): A Review. Pakistan Journal of Nutrition. 7(4): 513-520.

43. Vellini, M., Desideri, D., Milanese, A., Omini, G., Daffonchio, L., Hernandez, A. and Brunelli, G.,(1986) Possible involvement of eicosanoids in pharmacological action of bromelain, Arzneim-Forch/Drug Res, 36: 10-112.

44. www. wikipedia.com

45. www.encyclopedia.com

46. www.google.com 